\title{
EVALUASI KEBIJAKAN SABILULUNGAN 1000 KAMPUNG KABUPATEN BANDUNG
}

\author{
Anjar Pratama Apriliyanto ${ }^{1}$
}

\begin{abstract}
Bandung Regency Government adapted the concept of developing an integrated planning area that utilizes a local base with the spirit of sabilulungan (Sundanese: gotong royong) which tries to integrate various development sectors in one activity called "Sabilulungan 1000 Kampung". After two years of implementing this concept where the villages have begun to be developed, it is necessary to see the level of success through an appropriate evaluation mechanism. This study tries to see how the evaluation of the implementation of this policy is through interviews with purposive sampling to the stakeholders of this program. The analytical method used is to utilize 5 evaluation criteria, namely effectiveness, adequacy, equity, responsiveness and accuracy which is used to see how the program has been running for these 2 years. Based on the analysis, it is seen that although programs and activities have shown a tourist attraction that is built and implemented according to the agreed time, the lack of monitoring and evaluation needs to be improved to get more equitable, precise, and sustainable results. More detailed action plans are needed. and operational and alternative funding schemes can help overcome existing barriers.
\end{abstract}

Keywords: Evaluation; Policy; Sabilulungan 1000 Kampung

\section{PENDAHULUAN}

Pemerintah Kabupaten Bandung mengembangkan sebuah program bernama Sabilulungan 1000 Kampung yang mengedepankan perencanaan pembangunan terpadu untuk meningkatkan kesejahteraan dan perekonomian masyarakat berbasiskan potensi daerah. Selama keberjalanannya, program yang telah berjalan selama 2 (dua) tahun ini, terhitung dari tahun 2018 sebagai tahun pertama penerapan konsep ini di mana kampungkampung mulai dikembangkan, Pemerintah Kabupaten Bandung masih dihadapkan pada kondisi kesejahteraan masyarakat yang belum optimal. Hal ini meliputi di antaranya, laju pertumbuhan ekonomi yang tinggi namun tidak diiringi dengan pemerataan tenaga kerja.

\footnotetext{
${ }^{1}$ Politeknik STIA LAN Bandung
} 
Sebagai suatu kebijakan yang bertujuan untuk mendorong perekonomian masyarakat yang berbasiskan kearifan lokal yang terpadu, fenomena yang kurang optimal tersebut dapat mengindikasikan adanya proses yang kurang optimal pada tahap perencanaan maupun pada implementasi kebijakan. Akibatnya, hasil kegiatan dapat menjadi kurang efektif, kurang cukup, kurang merata, kurang responsif dan kurang tepat serta, pada konteks yang lebih luas, dapat mengindikasikan adanya hambatan dalam proses perencanaan dan implementasi Sabilulungan 1000 Kampung.

Pada konteks yang lebih makro, indikasi ini juga mendorong perencanaan pembangunan di Kabupaten Bandung untuk ditinjau kembali secara sistematis. Mulyono (2020) mengungkapkan adanya inkonsistensi pada tataran perencanaan yang tertuang dalam RPJMD dan RPKP dan realisasi Sabilulungan 1000 Kampung. Hal ini terungkap di antaranya pada perencanaan pelatihan kewirausahaan, sertifikasi halal, penataan kawasan kumuh, dan pembinaan BUMDes, sedangkan realisasi kegiatan yang dilakukan adalah terkait peningkatan teknologi hasil perkebunan, peningkatan kualitas SDM, penyediaan sarana dan prasarana perdesaan dan peningkatan produktivitas usaha kopi.

Ketika dikritisi lebih dalam, inkonsistensi tersebut dapat menunjukkan adanya upaya pembangunan yang fleksibel dan mempertimbangkan aspirasi serta kebutuhan masyarakat setempat. Akan tetapi, absensi suatu bentuk pengendalian yang tertuang dalam dokumen perencanaan Sabilulungan 1000 Kampung diargumentasikan dapat menghambat realisasi perencanaan pembangunan tersebut untuk dapat sesuai dengan kebutuhan masyarakat. Alhasil, muncul potensi akan implementasi perencanaan kebijakan publik yang tidak tepat sasaran. Studi ini berupaya mengevaluasi perencanaan dan implementasi Sabilulungan 1000 Kampung serta merumuskan indikator evaluasi yang dapat menjadi masukan untuk penyempurnaan konsep kebijakan pembangunan di Kabupaten Bandung kedepannya.

\section{Tinjauan Pustaka}

Bromley (1989) berpandangan bahwa kebijakan publik mencakup dua konsep mendasar. Pertama, secara sosial menentukan tatanan kelembagaan yang dapat diterima dalam menyusun struktur hak yang membatasi tindakan pribadi dan membebaskannya pada tingkat operasional. Kedua, mencari batasan antara otonomi atau kebebasan sebagaimana bekerjanya mekanisme suatu pasar dan pengambilan keputusan kolektif. Cara pandang Bromley bertitik tolak dari proses perubahan kelembagaan dalam rangka 
realokasi peluang ekonomi dan redistribusi pendapatan sekaligus untuk efisiensi dan efektivitas kelembagaan.

Pada tahap implementasi kebijakan, proses yang berlangsung dapat juga dipengaruhi oleh unsur politis dan evaluasinya pun harus memperhatikan baik substansi kebijakan namun juga konteks di mana kebijakan tersebut berlangsung. Menurut Grindle (2017), implementasi kebijakan merupakan suatu proses yang politis. Pada saat kebijakan tersebut dievaluasi maka tujuan pelaksanaan kebijakan tidak terlepas dari kepentingan, kuasa dan strategi para pelaku yang terlibat serta dampak dan perubahan yang kebijakan tersebut akibatkan. Perspektif ini juga menunjukkan bahwa proses perencanaan kebijakan dan proses implementasi kebijakan hingga outcomes dari kebijakan tersebut saling berkaitan dan evaluasinya perlu melihat kebijakan tersebut sebagai tiga rangkaian proses yang saling terkait. Pada penelitian ini, perspektif terkait implementasi kebijakan ini perlu menunjukkan bahwa evaluasi kebijakan Sabilulungan 1000 Kampung tidak hanya perlu dilihat dari segi substantif kebijakannya saja tapi perlu dilihat pada konteks politik di mana itu dilaksanakan. Dalam arti lain, kondisi politik kepemimpinan pada periode 20162021 juga mempengaruhi bagaimana kebijakan tersebut direncanakan, diimplementasi, dan bagaimana kebijakan tersebut mampu memberikan perubahan di masyarakat.

Kebijakan yang telah diformulasikan atau dirumuskan bermaksud untuk mencapai tujuan tertentu. Dalam konteks ini, dapat dimengerti apabila banyak kalangan yang berpendapat bahwa kebijakan tidak akan sukses jika dalam pelaksanaannya tidak ada kaitannya dengan tujuan yang telah ditetapkan. Untuk mengetahui sejauh mana pelaksanaan kebijakan mencapai tujuan yang telah ditetapkan maka tahap terakhir dari proses kebijakan adalah melakukan evaluasi kebijakan. Evaluasi kebijakan menekankan pada estimasi atau pengukuran dari suatu kebijakan, termasuk juga materi, implementasi, pencapaian tujuan, dan dampak dari kebijakan tersebut, bahkan evaluasi juga dapat digunakan untuk mengidentifikasi faktor-faktor yang mempengaruhi keberhasilan atau kegagalan suatu kebijakan sehingga hasil pengkajian tersebut dapat digunakan sebagai bahan pengambilan keputusan apakah kebijakan tersebut akan dilanjutkan, diubah, diperkuat atau diakhiri (Anderson, 1997: 272).

Kriteria dalam rangka mengevaluasi suatu kebijakan menurut Dunn (2003: 429499) mencakup 6 (enam) kriteria, yaitu efektivitas, efisiensi, kecukupan, perataan, responsitivitas, dan ketetapan. Rincian kriteria tersebut adalah sebagai berikut. 
1. Efektivitas, berkenaan dengan apakah suatu alternatif mencapai hasil (akibat) yang diharapkan, atau mencapai tujuan dari diadakannya tindakan. Yang secara dekat berhubungan dengan rasionalitas teknis, selalu diukur dari unit produk atau layanan atau nilai moneternya.

2. Efisiensi, berkenaan dengan jumlah usaha yang diperlukan untuk menghasilkan tingkat efektivitas tertentu. Kebijakan yang mencapai efektivitas tertinggi dengan biaya terkecil dinamakan efisien".

3. Kecukupan, berkenaan dengan seberapa jauh suatu tingkat efektivitas memuaskan kebutuhan, nilai, atau kesempatan yang menumbuhkan adanya masalah.

4. Perataan, berhubungan dengan rasionalitas legal dan sosial dan menunjuk pada distribusi akibat dan usaha antara kelompok-kelompok yang berbeda dalam masyarakat. Kunci dari perataan, yaitu keadilan atau kewajaran.

5. Responsifitas, berkenaan dengan seberapa jauh suatu kebijakan dapat memuaskan kebutuhan, preferensi, atau nilai kelompok-kelompok masyarakat tertentu.

6. Ketetapan, berkaitan dengan rasionalitas substantif karena kriteria ini menyangkut substansi tujuan bukan cara atau instrumen untuk merealisasikan tujuan tersebut.

\section{METODE PENELITIAN}

Studi ini secara garis besar menggunakan pendekatan kualitatif yang diperoleh dari data primer wawancara dan FGD dengan pemangku kepentingan di lapangan. Lokasi penelitian dilakukan pada lokus kampung, yakni unit pembangunan yang digunakan untuk perencanaan dan implementasi Sabilulungan 1000 Kampung. Dari 33 kampung yang berada di peta administrasi Kabupaten Bandung, hanya beberapa kampung yang dipilih sebagai objek studi penelitian ini. Pemilihan kampung tersebut didasari oleh pertimbangan spasial dan juga keterbatasan waktu yang dimiliki oleh peneliti.

Pertimbangan spasial pemilihan lokasi didasari oleh 8 Wilayah Pengembangan (WP) yang ada di Kabupaten Bandung yang pengembangannya diarahkan pada mixed use kawasan perdagangan dan jasa berbasis potensi lokal seperti pertanian, pariwisata dam industri. Dengan demikian, dipilih 3 (tiga) WP yang memiliki kriteria tersebut, yakni 1) WP Soreang-Kutawaringin-Katapang; 2) WP Banjaran; dan 3) WP Baleendah, yang berfungsi di antaranya sebagai kawasan pemerintahan, jasa dan perdagangan, pertanian, pariwisata dan industi. Kampung yang terdapat di dalam ketiga WP tersebut meliputi 
Kampung Gamis di WP Soreang-Kutawaringin-Katapang, Kampung Kopi di WP Banjaran dan Kampung Sepatu di WP Baleendah.

Informan wawancara dan FGD yang digunakan dalam penelitian ini ditentukan dengan menggunakan purposive, purposeful, atau criterion-based sampling. Secara lebih rinci, sumber dan informan dipilih dengan kriteria dan pertimbangan sebagai berikut:

1. Para tokoh dipilih karena dianggap ikut serta dalam perencanaan dan pelaksanaan serta memperoleh dampak langsung dari program Sabilulungan 1000 Kampung yang diterapkan di Kabupaten Bandung.

2. Unsur BAPPEDA Kabupaten Bandung dipilih karena mereka terlibat dalam perencanaan kebijakan pembangunan program Sabilulungan 1000 Kampung di Kabupaten Bandung.

3. Unsur perangkat daerah Kabupaten Bandung dipilih karena mereka terlibat dalam implementasi kebijakan pembangunan program Sabilulungan 1000 Kampung di Kabupaten Bandung.

\section{HASIL DAN PEMBAHASAN}

\section{Perencanaan Sabilulungan 1000 Kampung}

Musrenbang Kabupaten Bandung tahun 2018 diantaranya melahirkan kebijakan Sabilulungan 1000 Kampung guna menciptakan pembangunan kampung yang terintegrasi dan berbasis lingkungan. Tindak lanjut dari penyusunan RKPD 2019 menghasilkan konsultasi publik yang diselenggarakan pada 1 Februari 2018 dan rangkaian perencanaan lainnya yang berupaya menciptakan fondasi kebijakan Sabilulungan 1000 Kampung. Fondasi tersebut dikembangkan oleh perwakilan perangkat daerah, stakeholder maupun masyarakat, di bawah koordinasi dari Bappeda Kabupaten Bandung.

Seiring berjalannya kebijakan Sabilulungan 1000 Kampung di tiga kampung terpilih, dapat terlihat adanya perkembangan aktivitas perekonomian lokal di ketiga kampung tersebut. Terutama pada tahun 2018, terjadi peningkatan yang signifikan di ketiga kampung terpilih dalam penelitian ini. Akan tetapi, pada tahun 2019 melalui RKPD 2020 Pemerintah Kabupaten Bandung menetapkan priortas pengembangan kampung di luar tiga kampung yang menjadi fokus penelitian ini sehingga dapat menjelaskan rendahnya perkembangan yang dialami pada tahun 2019 . 
Meski pergantian fokus kampung di tahun 2019 menunjukkan upaya pemerataan intervensi dari Pemerintah Kabupaten Bandung, namun upaya tersebut nampaknya kurang dapat diseimbangi dengan upaya keberlanjutan pada kampung-kampung yang menjadi fokus pada tahun-tahun sebelumnya. Padahal, keberlanjutan tersebut dapat terjadi apabila intervensi pengembangan tidak hanya melalui pemberian modal atau pembangunan fisik dari pemerintah setempat, namun juga mencakup intervensi pemberdayaan masyarakat khususnya para pelaku usaha agar dapat mandiri dari intervensi pemerintah sesaat.

\section{Evaluasi Proses dan Implementasi Kebijakan Sabilulungan 1000 Kampung}

Dalam keberjalanannya, Pemerintah Kabupaten Bandung telah menetapkan sebanyak 33 kampung untuk dibangun selama periode perencanaan jangka menengah dalam RPJMD Kabupaten Bandung Tahun 2016-2021. Program ini kemudian ditindaklanjuti dalam Rencana Pengembangan Kawasan Perdesaan yang disusun oleh Bappeda Kabupaten Bandung. Adapun pada proses penyusunan dokumen tersebut dilibatkan berbagai perangkat daerah terkait, seperti Dinas Koperasi dan UKM, Dinas Perdagangan dan Perindustrian, Dinas Pertanian, Dinas Pekerjaan Umum dan Penataan Ruang, Dinas Perhubungan, Dinas Perumahan, Kawasan Permukiman dan Pertanahan, Dinas Tenaga Kerja, DP2KBP3A, Dinas Perpustakaan dan Arsip, Dinas Komunikasi, Informatika dan Statistika, dan Dinas Pemberdayaan Masyarakat dan Desa.

Pada penelitian Mulyono (2020), ditemukan bahwa terdapat beberapa perencanaan pengembangan kegiatan turunan 1000 Kampung yang dimuat di dalam RPJMD dan RPKP yang realisasinya tidak sesuai di antaranya meliputi program pelatihan kewirausahaan, sertifikasi halal, penataan kawasan kumuh, dan pembinaan BUMDes, sedangkan realisasi kegiatan yang dilakukan adalah terkait peningkatan teknologi hasil perkebunan, peningkatan kualitas SDM, penyediaan sarana dan prasarana perdesaan dan peningkatan produktivitas usaha kopi. Hal ini dapat mengindikasikan adanya proses cascading perencanaan kegiatan yang tidak sesuai dengan muatan kebijakan pada hierarki di atasnya.

Berdasarkan penjabaran kegiatan yang telah dilaksanakan di Kampung Gamis, Kampung Kopi, dan Kampung Sepatu pada tahun 2018, diketahui bahwa konsep pembangunan tematik telah berhasil untuk meningkatkan sinkronisasi dan keterpaduan (integrasi) dari berbagai sektor pemerintahan di Kabupaten Bandung. Hal ini dapat dilihat 
dari beragamnya Perangkat Daerah, baik pada bidang fisik, ekonomi, maupun sosial, yang melaksanakan program dan kegiatannya di lokasi kampung. Dalam melaksanakan kegiatannya, Perangkat Daerah tetap bergerak pada kewenangan urusan yang di bawahinya, namun dengan tujuan yang sama, yakni membangun kampung sesuai dengan tematik yang telah ditetapkan dengan semangat 'sabilulungan' (gotong royong). Kerja sama antar Perangkat Daerah yang tercipta dari pelaksanaan kebijakan pembangunan Sabilulungan 1000 Kampung memungkinkan terciptanya efektivitas dan efisiensi pembangunan pada tiap kampung.

Secara umum, evaluasi proses perencanaan dan implementasi Sabilulungan 1000 Kampung dapat memenuhi kriteria efektivitas, kecukupan, pemerataan, responsivitas dan ketepatan. Meski demikian, proses perencanaan maupun implementasi kebijakan ini masih bisa ditingkatkan, yakni dengan memperluas intervensi di luar intervensi fisik, melanjutkan proses pembinaan masyarakat pada rentang waktu yang lebih lama dan memperhatikan segi kontinuitas kepemimpian. Secara lebih rinci. Berikut adalah pemaparan analisis untuk masing-masing kriteria.

\section{A. Efektivitas}

Efektivitas adalah ketercapaian target program dan kegiatan, penggunaan sumber daya anggaran, peran stakeholder dan multisektoral, keterlibatan masyarakat, dan pewaktuan dari pelaksanaan kebijakan. Jika dikaitkan dengan teori Dunn (2003), efektivitas tercapai apabila nilai outcome yang diharapkan dapat terwujud. Dalam hal ini, outcome yang diharapkan dengan adanya Sabilulungan 1000 Kampung adalah perencanaan perdesaan yang terintegrasi dan berbasis potensi kampung.

Berdasarkan penjabaran aspek efektivitas di atas maka dapat diketahui bahwa pelaksanaan kebijakan Sabilulungan 1000 Kampung dapat dinyatakan cukup efektif apabila melihat dari sisi ketercapaian target program dan kegiatan, penggunaan sumber daya anggaran, peran stakeholder dan multisektoral, keterlibatan masyarakat, dan pewaktuan dari pelaksanaan kebijakan. Akan tetapi, pengembangan kampung bukan hanya sebatas pembangunan fisik dan pembinaan masyarakat dan ekonomi yang cukup dilaksanakan dalam kurun waktu satu tahun saja, melainkan membutuhkan perhatian dari pemerintah yang berlanjut menyesuaikan kebutuhan-kebutuhan masyarakat yang terus berkembang untuk mampu menjadikan kampung yang berkelanjutan. 
B. Kecukupan

Dalam penelitian ini, kecukupan dikaitkan pada tujuan penyelenggaraan Sabilulungan 1000 Kampung, yakni perencanaan tematik menuju terwujudnya Kabupaten Bandung yang maju, mandiri, dan berdaya saing (Zulfikar dan Witartih, 2020). Jika dikaitkan dengan teori Dunn (2003), kriteria kecukupan terpenuhi apabila hasil yang dihasilkan mampu menyelesaikan masalah yang diidentifikasi di awal. Dalam hal ini, perlu dilihat sejauh mana hasil kebijakan Sabilulungan 1000 Kampung, baik yang ditinjau secara proses perencanaannya maupun implementasi kebijakan terkait, mampu mengatasi permasalahan Kabupaten Bandung, yakni terkait peningkatan perekonomian dan pemberdayaan masyarakat perdesaan. Meninjau hasil penelitian berkaitan dengan kriteria kecukupan seperti yang dijelaskan sebelumnya maka dapat disimpulkan bahwa kecukupan dari pelaksanaan kebijakan Sabilulungan 1000 Kampung dapat dikatakan kurang optimal, dalam artian kebijakan ini sudah mampu meningkatkan daya saing kampung apabila ditinjau dari segi pembangunan pada bidang fisiknya saja.

Namun, jika ditinjau dari segi pembangunan sumber daya manusia sebagai pelaku pembangunan, pemerintah masih belum mampu memberikan intervensi yang optimal. Selain itu, pengawasan terhadap pelaksanaan kebijakan ini juga dapat dikatakan cukup, meskipun untuk mekanisme pengajuan usulan yang menjadi tindak lanjut dari adanya ketidaksesuaian dari pembangunan baru dapat dilaksanakan pada tahun berikutnya, mengingat usulan pada Musrenbang Desa baru dapat diakomodir dalam Musrenbang Kabupaten pada tahun berikutnya.

C. Pemerataan

Dikaitkan dengan kriteria evaluasi Dunn (2003), pemerataan terpenuhi apabila outcome kebijakan dapat dimanfaatkan oleh seluruh lapisan masyarakat. Dalam hal ini, proses penyusunan rencana Sabilulungan 1000 Kampung dan implementasi programnya harus dapat mendistribusikan manfaat maupun risiko ke seluruh elemen dalam pentahelix. Berdasarkan hasil pengumpulan informasi di atas, dapat disimpulkan bahwa dari segi pemerataan, pemerintah telah mengupayakan untuk mampu memberikan manfaat yang merata bagi seluruh masyarakat kampung. Pada proses penyusunan rencana, pemerataan dilakukan dengan pemberian kesempatan yang terbuka bagi seluruh elemen stakeholder pentahelix untuk memberikan masukan, terutama pada saat pelaksanaan musrenbang. 
Tetapi pada pelaksanaannya, tentu pembangunan yang dilakukan belum mampu dirasakan secara merata dan setara bagi lapisan masyarakat yang satu dan lainnya. Hal ini karena program dan kegiatan yang dilaksanakan oleh Perangkat Daerah memiliki target/objek pembangunan tertentu sehingga hanya objek pembangunan tersebut saja yang akan merasakan manfaat langsung dari pelaksanaan program dan kegiatan terkait. Terlebih lagi, hal ini juga dibuktikan dengan belum adanya wadah berbadan hukum yang memayungi kelembagaan di desa dan antardesa untuk pelaksanaan Sabilulungan 1000 Kampung maka dari itu, dapat disimpulkan bahwa pelaksanaan kebijakan Sabilulungan Bandung 1000 Kampung belum mampu memberikan manfaat yang merata bagi masyarakat secara optimal.

\section{Responsivitas}

Dikaitkan dengan kriteria Dunn (2003), responsivitas terpenuhi apabila kebijakan terkait mampu memenuhi kebutuhan, preferensi atau nilai-nilai yang dianut bersama oleh para stakeholder yang terlibat. Dalam hal ini, tidak hanya menekankan pada pelaksanaan program yang baik namun juga proses perencanaan yang inklusif, terbuka dan dapat dipertanggungjawabkan. Berdasarkan penjabaran kriteria responsivitas tersebut, didapatkan bahwa secara garis besar masyarakat memberikan respon positif terhadap pelaksanaan kebijakan Sabilulungan 1000 Kampung dan sudah merasa cukup puas atas dampak dari pembangunan yang dilakukan oleh pemerintah. Akan tetapi, pemerintah masih perlu mengoptimalkan proses perencanaan yang inklusif dan terbuka agar rencana yang dikembangkan sudah sesuai dengan kebutuhan stakeholder dari awal serta pelaksanaan program dan kegiatan yang dilaksanaan di kampung mengingat masih banyaknya proses dalam pengembangan kampung yang perlu diintervensi oleh pemerintah demi mewujudkan kampung yang berkelanjutan.

\section{E. Ketepatan}

Pada dasarnya, implementasi program dan kegiatan yang dilaksanakan oleh Perangkat Daerah dalam menunjang kebijakan Sabilulungan 1000 Kampung sudah mampu menjawab sebagian tujuan dari kebijakan ini, yakni menciptakan pembangunan daerah yang berbasis multisektoral. Hal ini diwujudkan oleh banyaknya Perangkat Daerah yang terlibat dalam pembangunan yang membawahi berbagai urusan dari bidang fisik, sosial, dan ekonomi. Akan tetapi, apabila melihat hasil pembangunan yang telah dilaksanakan, kesinambungan antar pembangunan yang dilaksanakan Perangkat Daerah 
masih belum mampu terwujud. Pembangunan memang dilaksanakan secara 'sabilulungan' atau gotong royong, namun benang merah pembangunan dengan mengedepankan tema tertentu masih belum dapat terrealisasikan. Perangkat Daerah telah melaksanakan pembangunan pada lokasi-lokasi yang ditetapkan sebagai kampung pada tahun anggaran yang telah ditetapkan pada rencana jangka menengah, namun masih sebatas pelaksanaan program dan kegiatan reguler/business as usual, dan belum dapat menyalurkan semangat Sabilulungan 1000 Kampung, yakni pembangunan tematik.

Jika dikaitkan dengan teori Dunn (2003), kriteria evaluasi ketepatan terpenuhi apabila outcome kebijakan dapat menghasilkan sesuatu yang bernilai. Dari informasi tersebut, dapat diketahui bahwa kriteria ketepatan dalam pelaksanaan kebijakan Sabilulungan 1000 Kampung masih kurang karena masih banyaknya indikator yang dianggap belum dapat terpenuhi, khususnya pada perwujudan tujuan dari kebijakan publik ini.

\section{Permasalahan dan Hambatan Sabilulungan 1000 Kampung}

Berdasarkan hasil analisis, beberapa hambatan yang ditemukan adalah terkait belum memadainya SDM dan infrastruktur pendukung pariwisata secara terpadu. Sebagai ilustrasi, Kampung Sepatu merupakan salah satu kampung dengan industri yang berkembang jika dilihat dari volume usaha dan besarnya permintaan pasar. Meski demikian, kurangnya kapasitas pelaku usaha dalam mengembangkan usahanya sendiri dan kurangnya infrastruktur seperti mesin maupun infrastruktur regional yang memungkinkan pariwisata pada skala yang besar mengakibatkan para pelaku usaha lebih cenderung menerima pesanan untuk merk ternama.

Berdasarkan pemaparan umum dari beberapa informan di atas, dapat disimpulkan bahwa Kabupaten Bandung memiliki banyak potensi untuk mendukung perekonomian masyarakat yang hidup dan berbasis kearifan lokal. Adanya pengembangan program Sabilulungan 1000 Kampung harapannya dapat mengakselerasi dan semakin mengintegrasikan pembangunan yang ada di masing-masing desa dan kampung. Meski demikian, masih ditermukan beberapa hambatan dalam proses perencanaan dan implementasi kebijakan Sabilulungan 1000 Kampung.

Jika dikaitkan dengan pendekatan evaluasi Dunn (2003), potensi dan hambatan yang ditemukan mencerminkan pembangunan yang dinamis, yakni bahwa potensi dan hambatan yang ada di setiap desa dapat jalan beriringan dan saling terkait dengan satu 
sama lain. Terlebih lagi, dinamika tersebut dapat lebih signifikan dalam konteks adanya pergantian kepemimpinan, seperti halnya terjadi di Kabupaten Bandung pada tahun 2020.

Dalam hal ini, kriteria Dunn (2003) kurang optimal dalam menjelaskan dinamika hambatan dan potensi dalam rentang waktu yang berjenjang. Meski demikian, kriteria Dunn (2003) dapat mencerminkan evaluasi untuk memperbaiki keberjalanan suatu kebijakan dari beragam perspektif, terutama pada lokus kebijakan yang lebih kecil, yakni tingkat kampung.

Berdasarkan paparan tersebut, maka hambatan yang dihadapi berdasarkan masingmasing komponen Dunn (2003) adalah sebagai berikut:

Tabel 1. Analisis SWOT Terhadap Hambatan Pada Komponen Dunn (2003)

\begin{tabular}{|c|c|c|}
\hline No & Komponen & Hambatan yang Dihadapi \\
\hline 1 & Efektivitas & $\begin{array}{l}\text { - Kegiatan dilakukan secara sporadis tanpa adanya integrasi dan } \\
\text { keterpaduan antardinas. Hal ini bisa menyebabkan manfaat yang } \\
\text { bisa dicapai tidak bisa maksimal dan efektif. } \\
\text { - Sharing knowledge juga menjadi hal yang sulit dilakukan ketika } \\
\text { sebuah perkumpulan tidak terintegrasi dengan baik. Akibatnya } \\
\text { hal yang bisa dilakukan dengan singkat akan sulit dilakukan } \\
\text { karena butuh pembelajaran dari awal kembali. } \\
\text { - Selain itu, peran serta masyarakat juga terdapat pada pelaksanaan } \\
\text { pascapembangunan yang dilaksanakan pemerintah. Dalam } \\
\text { pelaksanaan terkadang masyarkat hanya menunggu inisiatif dari } \\
\text { pemerintah dan tidak melakukan inisiatif pribadi untuk } \\
\text { melakukan pengawasan dan pengendalian harian yang } \\
\text { dibutuhkan. }\end{array}$ \\
\hline 2 & Kecukupan & $\begin{array}{l}\text { - Dalam mendukung kegiatan yang dilakukan oleh para pelaku } \\
\text { usaha, pemerintah daerah harus mampu mengidentifikasi } \\
\text { kebutuhan dengan tepat. Saat ini pemerintah daerah menganggap } \\
\text { pemberian pelatihan dan pembinaan adalah bantuan yang } \\
\text { dibutuhkan oleh para pelaku usaha. Namun seringkali pemberian } \\
\text { pelatihan dan pembinaan ini bukan hal yang masyarakat } \\
\text { harapkan. } \\
\text { - Selain itu, pemberian pelatihan dan pembinaan dirasa belum } \\
\text { mencukupi karena terkendala dalam hal mengidentifikasi } \\
\text { sedalam apa kebutuhan para peserta pelatihan dalam membantu } \\
\text { proses kegiatan mereka. } \\
\text { Kegiatan pelatihan dan pembinaan yang dilaksanakan oleh } \\
\text { pemerintah masih sangat terbatas dan belum mendalam dan } \\
\text { mampu memberikan pengetahuan bagi pelaku usaha di kampung } \\
\text { untuk mampu mengolah sumber daya dan potensi yang ada di } \\
\text { kampung mulai dari hulu sampai dengan hilir, mulai dari } \\
\text { produksi sampai dengan pemasaran. }\end{array}$ \\
\hline 3 & Pemerataan & $\begin{array}{l}\text { - Dampak dan manfaat yang diharapkan dari Sabilulungan } \\
\text { Bandung } 1000 \text { Kampung baru mampu dirasakan oleh } \\
\text { masyarakat secara luas setelah kegiatan perekonomian di } \\
\text { kampung telah mampu berkembang dan memberikan multiplier }\end{array}$ \\
\hline
\end{tabular}




\begin{tabular}{|c|c|c|}
\hline No & Komponen & Hambatan yang Dihadapi \\
\hline & & $\begin{array}{l}\text { effects kepada kegiatan-kegiatan lain yang ada di kampung. } \\
\text { Artinya, pemerataan manfaat dari kebijakan ini tidak dapat } \\
\text { dirasakan secara langsung oleh seluruh lapisan masyarakat, } \\
\text { melainkan membutuhkan proses pengembangan yang } \\
\text { berkelanjutan. } \\
\text { - Pada pelaksanaannya, tentu pembangunan yang dilakukan belum } \\
\text { mampu dirasakan secara merata dan setara bagi lapisan } \\
\text { masyarakat yang satu dan lainnya. Hal ini karena program dan } \\
\text { kegiatan yang dilaksanakan oleh Perangkat Daerah memiliki } \\
\text { target/objek pembangunan tertentu sehingga hanya objek } \\
\text { pembangunan tersebut saja yang akan merasakan manfaat } \\
\text { langsung dari pelaksanaan program dan kegiatan terkait. }\end{array}$ \\
\hline 4 & Responsivitas & $\begin{array}{l}\text { - Masyarakat mampu merespon secara positif terkait pelaksanaan } \\
\text { kebijakan Sabilulungan Bandung } 1000 \text { Kampung dan sudah } \\
\text { merasa cukup puas atas dampak dari pembangunan yang } \\
\text { dilakukan oleh pemerintah. } \\
\text { - Namun dalam hal ini perlu dipastikan lagi bahwa memang benar } \\
\text { keseluruhan masyarakat dapat menjawab jujur pertanyaan yang } \\
\text { diajukan dalam pemberian feedback tanpa adaya unsur politis } \\
\text { yang melatarbelakngi itu. Masyarakat yang memberikan respon } \\
\text { diharapkan orang yang mampu mengetahui proses serta manfaat } \\
\text { yang dilakukan dalam pelaksanaan kebijakan Sabilulungan } \\
\text { Bandung } 1000 \text { Kampung. }\end{array}$ \\
\hline 5 & Ketepatan & $\begin{array}{l}\text { - Meski implementasi program dan kegiatan yang dilaksanakan } \\
\text { oleh Perangkat Daerah dalam menunjang kebijakan } \\
\text { Sabilulungan Bandung } 1000 \text { Kampung sudah mampu menjawab } \\
\text { sebagian tujuan dari kebijakan ini, yakni menciptakan } \\
\text { pembangunan daerah yang berbasis multisektoral, namun } \\
\text { benang merah pembangunan dengan mengedepankan tema } \\
\text { tertentu masih belum dapat terealisasikan. } \\
\text { - Pembangunan pada lokasi-lokasi yang ditetapkan sebagai } \\
\text { kampung pada tahun anggaran yang telah ditetapkan pada } \\
\text { rencana jangka menengah masih sebatas pelaksanaan program } \\
\text { dan kegiatan reguler/business as usual, dan belum dapat } \\
\text { menyalurkan semangat Sabilulungan Bandung } 1000 \text { Kampung, } \\
\text { yakni pembangunan tematik. }\end{array}$ \\
\hline
\end{tabular}

Sumber: Olahan data penulis

Berdasarkan hambatan yang ada, hampir sebagian besar hambatan yang ada adalah kurangnya pengawasan, kurangnya keterlibatan masyarakat, kurangnya pemberdayaan sumber daya manusia, kurangnya inovasi, dan kurangnya pemertaan biaya dan manfaat yang dihasilkan dari kebijakan Sabilulungan 1000 Kampung. Jika dikaitkan dengan teori Dunn (2003), hambatan-hambatan yang ada dapat berdampak pada efektivitas, kecukupan, pemerataan, responsivitas, dan ketepatan program. Identifikasi dan analisis hambatan yang ada di ketiga studi kasus penelitian juga menunjukan permasalahanpermasalahan serupa terkait kurangnya pemberdayaan SDM pelaku usaha, minimnya 
inovasi dan akses ke pasar yang lebih luas, dan infrastruktur yang memadai, meskipun semangat berusaha dan sifat gotong royongnya tinggi di kalangan masyarakat, khususnya pelaku usaha di kampung-kampung terkait. Rincian analisis SWOT tersebut dapat dilihat pada Tabel 2.

Hasil studi juga diperkuat dengan keterangan dari beberapa informan di lingkungan pemerintahan yang menyatakan bahwa masih terdapat hambatan sumber daya manusia dan infrastruktur yang mendukung pengembangan Menurut Kepala BAPPEDA Kab. Bandung terkait hambatan dalam pelaksanaan kebijakan Sabilulungan 1000 Kampung, dalam wawancara tanggal 1 November 2020, yaitu:

"Secara garis besar, proses impelementasi kebijakan ini sudah berjalan dengan baik namun masih terkendala terutama dalam hal infrastruktur dan sumber daya manusia yang siap dalam menghadapi kemunculan industry 4.0. Hambatan terkait infrastruktur ini bukan hal yang bisa dilaksanakan dengan cepat, meski menghambat namun kita bisa memanfaatkan potensi lain dan tidak berfokus kepada apa yang menghambat. Penjualan dan wisata bisa tetap berjalan dengan infrastruktur yang ada, selagi kita terus memperbaiki hal tersebut. Hal ini akan kami dorong dalam perencanaan RPJMD tahun 2021-2025 karena hambatan ini harus diselesaikan dengan kerjasama dan kolaborasi dari berbagai sektor agar bisa terlaksana dengan baik."

Menurut Pak Camat, Kecamatan Soreang terkait hambatan dalam pelaksanaan kebijakan

Sabilulungan 1000 Kampung, dalam wawancara tanggal 3 November 2020, yaitu:

"Potensi yang ada di kampung ini adalah potensi yang unik dan sangat bisa menjadi daya tarik wisata yang bermanfaat bagi penduduk sekitar. Namun penduduk sekitar pun perlu dipersiapkan untuk menjalani kegiatan wisata ini dengan sungguh-sungguh seperti mulai menumbuhkan warung oleh-oleh ataupun homestay karena saat ini akomodasi penginapan untuk turis di sekitar kampung gamis masih kurang. Meskipun ada hotel namun mungkin beberapa wisatawan ingin lebih dekat dengan peduduk sekitar melalui homestay"

Menurut Pak Camat, Kecamatan Dayeuhkolot terkait hambatan dalam pelaksanaan kebijakan Sabilulungan 1000 Kampung di Kampung Sepatu, dalam wawancara tanggal 2 November 2020, yaitu:

"Daerah ini meskipun dekat dengan pusat kota Bandung namun masih memiliki beberapa permasalahan terkait moda angkutan dan infrastruktur lainnya. Saat malam penerangan masih sulit hal ini bisa berbahaya jika ada turis yang tidak tahu wilayah setempat dan kesasar atau kena hal kriminal. Belum terdapat tempat pembuangan sampah sementara dan pengolahan limbah perkebunan dan juga belum terdapat signal menuju atraksi wisata bisa menyebabkan turis juga bingung saat datang kesini. Meskipung banyak pengerajin sepatu namun kami tidak yakin banyak anak muda yang masih mau berbelanja produk lokal." 
Menurut Pak Camat, Kecamatan Pangalengan terkait hambatan dalam pelaksanaan kebijakan Sabilulungan 1000 Kampung di Kampung Kopi, dalam wawancara tanggal 2 November 2020, yaitu:

"Daerah ini meskipun dekat dengan area wisata Ciwidey tetap saja massih kurang dalam pengembangan homestay yang bisa meningkatkan pendapatan warga sekitar karena kebanyakan villa-villa yang ada bukan dimiliki oleh penduduk asli sini. Selain itu, area ini merupakan area yang sering terjadi bencana alam seperti puting beliung menyebabkan kegagalan panen dan kerusakan infrastruktur. Masyarakat di sini juga belum mendapatkan pelatihan yang baik terkait bagaimana pengembangan ekonomi kreatif dan sumber daya manusia untuk menghadapi wisata"

\section{Alternatif Solusi}

Berdasarkan hasil analisis, ditemukan bahwa teori Dunn (2003) kurang dapat menjelaskan dinamika kebijakan yang ada di lapangan pada waktu yang berjenjang. Salah satu hambatan terbesar yang dihadapi juga adalah adanya dinamika politik kepemimpinan daerah. Meskipun kebijakan Sabilulungan 1000 Kampung memiliki potensi yang besar, walau masih perlu dikembangkan, keberlangsungan program ini sangat tergantung pada kepemimpinan selama RPJMD 2016-2021. Artinya, keberlanjutan kriteria efektivitas, kecukupan, pemerataan, responsivitas, dan ketepatan program dapat kurang berkelanjutan.

Oleh karena itu, alternatif solusi yang ditawarkan adalah penguatan monitoring dan evaluasi yang bisa dimulai dengan pembuatan roadmap yang jelas dan operasional untuk dilakukan secara jangka panjang dan mudah dipahami oleh para pelaku kegiatan, pelibatan masyarakat dalm gugus tugas khusus Sabilulungan 1000 Kampung, pengembangan database yang transparan dan terintegrasi dengan data eksisting di Kabupaten Bandung, dan pemerataan biaya dan manfaat dengan penguatan forward and backward linkages melalui peran pemangku kepentingan dan fokus kegiatan di lingkup sub-kampung. Adapun konteks politik yang mengawal keberlangsungan dan keberlanjutan program ini membutuhkan perencanaan dan intervensi yang lebih sistematis, seperti menguatkan kualitas dan signifikansi perencanaan pembangunan jangka panjang dalam pembangunan Kabupaten Bandung. 
Tabel 2. Analisis Isu Strategis di Tiga Lokasi Studi

\begin{tabular}{|c|c|c|c|c|}
\hline \multirow{2}{*}{ No } & \multirow{2}{*}{ Komponen } & \multicolumn{3}{|c|}{ Kondisi yang dihadapi } \\
\hline & & Kampung Gamis & Kampung Kopi & Kampung Sepatu \\
\hline 1 & $\begin{array}{l}\text { Strength }(\mathrm{S})- \\
\text { Opportunity }(\mathrm{O})\end{array}$ & 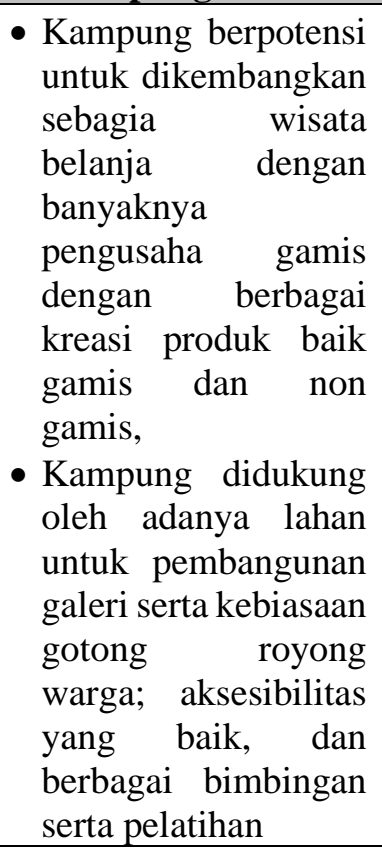 & $\begin{array}{l}\text { - Kampung Kopi dapat } \\
\text { dikembangkan lebih } \\
\text { lanjut dengan adanya } \\
\text { lahan yang masih } \\
\text { bisa dimanfaatkan } \\
\text { untuk kebun maupun } \\
\text { usaha, sub terminal } \\
\text { kampung kopi, mobil } \\
\text { wisata, homestay, } \\
\text { aksesbilita baik, } \\
\text { serta keinginan } \\
\text { warga untuk } \\
\text { mengembangkan } \\
\text { wisata edukasi yang } \\
\text { didukung dengan } \\
\text { atraksi wisata Situ } \\
\text { Cipeuceuk. }\end{array}$ & $\begin{array}{lr}\text { - Kampung } & \text { Sepatu } \\
\text { dapat dikembangkan } \\
\text { dengan } \\
\text { memanfaatkan } \\
\text { digitalisasi r } \\
\text { commerce } & e- \\
\text { memperluas } & \\
\text { jangkauan } & \\
\text { pemasarannya. }\end{array}$ \\
\hline 2 & $\begin{array}{l}\text { Weakness (W) - } \\
\text { Opportunity (T) }\end{array}$ & 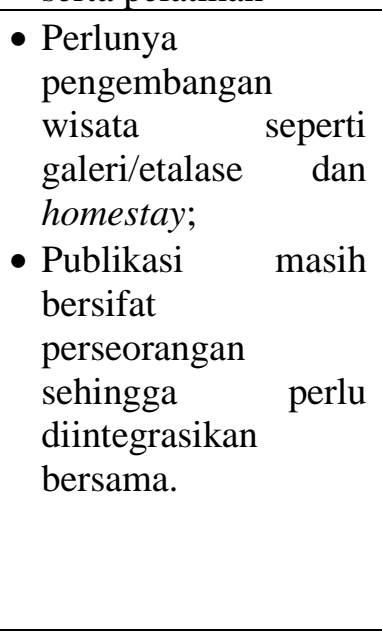 & $\begin{array}{l}\text { - Kurangnya moda } \\
\text { angkutan wisata } \\
\text { berkapasitas besar, } \\
\text { kurangnya } \\
\text { kerjasama/gotong } \\
\text { royong dalam } \\
\text { pengembangan } \\
\text { wisata, kurangnya } \\
\text { homestay, belum } \\
\text { adanya pusat oleh- } \\
\text { oleh dan fasilitas } \\
\text { penunjang wisata di } \\
\text { sub terminal, dan } \\
\text { sebagainya }\end{array}$ & $\begin{array}{l}\text { - Kurangnya moda } \\
\text { angkutan wisata } \\
\text { berkapasitas besar, } \\
\text { kurangnya } \\
\text { kerjasama/gotong } \\
\text { royong dalam } \\
\text { pengembangan } \\
\text { wisata, kurangnya } \\
\text { homestay, belum } \\
\text { adanya pusat oleh- } \\
\text { oleh dan fasilitas } \\
\text { penunjang wisata di } \\
\text { sub terminal, dll }\end{array}$ \\
\hline 3 & $\begin{array}{l}\text { Strength }(\mathrm{S})- \\
\text { Threat }(\mathrm{T})\end{array}$ & 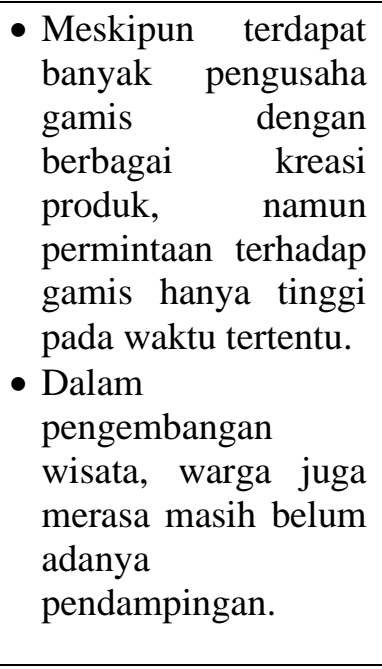 & 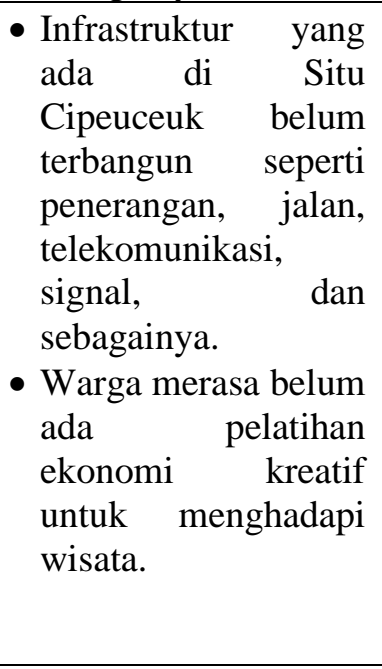 & $\begin{array}{l}\text { - Di Desa Cangkuang } \\
\text { Kulon tidak terdapat } \\
\text { mata air, fasilitas } \\
\text { buang air besar } \\
\text { mayoritas keluarga } \\
\text { berupa jamban } \\
\text { bersama, terdapat } \\
\text { tempat pembuangan } \\
\text { sampah sementara } \\
\text { dan digunakan, } \\
\text { terdapat penerangan } \\
\text { di sebagian besar } \\
\text { jalan utama, sinyal } \\
\text { telepon/handphone } \\
\text { kuat di sebagian }\end{array}$ \\
\hline
\end{tabular}




\begin{tabular}{|c|c|c|c|c|}
\hline \multirow{3}{*}{ No } & \multirow{3}{*}{ Komponen } & \multicolumn{3}{|c|}{ Kondisi yang dihadapi } \\
\hline & & Kampung Gamis & Kampung Kopi & Kampung Sepatu \\
\hline & & & & $\begin{array}{lr}\text { besar } & \text { wilayah, } \\
\text { mudah } & \text { untuk } \\
\text { mencapai } & \text { pasar, dan } \\
\text { terdapat } & \\
\text { kebiasaan/keterlibata } \\
\text { n sebagian } \\
\text { warga } & \text { kecil } \\
\text { kegiatan } & \text { galam } \\
\text { royong. } & \end{array}$ \\
\hline 4 & $\begin{array}{l}\text { Weakness }(\mathrm{W})- \\
\text { Threat }(\mathrm{T})\end{array}$ & $\begin{array}{l}\text { - Untuk } \\
\text { mengembangkan } \\
\text { wisata beberapa hal } \\
\text { yang dirasa kurang } \\
\text { oleh warga seperti } \\
\text { belum ada signage } \\
\text { menuju atraksi } \\
\text { wisata, kaulitas } \\
\text { sinyal dan kondisi } \\
\text { jalan kurang baik, } \\
\text { serta belum ada } \\
\text { galeri/etalase } \\
\text { lengkap dengan } \\
\text { infrastrukturnya. }\end{array}$ & $\begin{array}{l}\text { - Kondisi di Kampung } \\
\text { Kopi saat ini } \\
\text { infrastruktur } \\
\text { perkebunan belum } \\
\text { terpelihara dengan } \\
\text { baik setelah bencana } \\
\text { alam putting beliung } \\
\text { yang terjadi, selain } \\
\text { itu pembangunan } \\
\text { fasilitas penunjang } \\
\text { wisata di sub } \\
\text { terminal Kampung } \\
\text { Kopi juga belum } \\
\text { terbangun. }\end{array}$ & $\begin{array}{l}\text { - Kondisi di Kampung } \\
\text { Sepatu saat ini adalah } \\
\text { kemampuan SDM } \\
\text { yang meski telah } \\
\text { terlatih dalam } \\
\text { pembuatan sepatu } \\
\text { namun masih sulit } \\
\text { memasuki jaringan } \\
\text { pasar global dan sulit } \\
\text { untuk mengikuti } \\
\text { kemajuan digitalisasi } \\
\text { yang cukup pesat. } \\
\text { Minat pasar terkait } \\
\text { model sepatu dan } \\
\text { lemahnya citra } \\
\text { produk local masih } \\
\text { menjadi ancaman. }\end{array}$ \\
\hline
\end{tabular}

Sumber: Hasil olahan penulis, 2021

\section{KESIMPULAN}

Berdasarkan kriteria evaluasi Dunn (2003) maka kriteria yang paling terpenuhi adalah kriteria Efektivitas dan Responsivitas. Adapun kriteria yang paling belum terpenuhi adalah Kecukupan, Pemerataan, Ketepatan. Dari aspek hambatan dan solusi yang dikembangkan untuk senantiasa memperbaiki kebijakan Sabilulungan 1000 Kampung, hampir sebagian besar hambatan yang ada berkaitan dengan kurangnya pengawasan, kurangnya keterlibatan masyarakat, kurangnya pemberdayaan sumber daya manusia, kurangnya inovasi, dan kurangnya pemertaan biaya dan manfaat yang dihasilkan dari kebijakan Sabilulungan 1000 Kampung. Jika dikaitkan dengan teori Dunn (2003), hambatan-hambatan yang ada dapat berdampak pada efektivitas, kecukupan, pemerataan, responsivitas, dan ketepatan program Sabilulungan 1000 Kampung, berdasarkan permasalahan yang ditemukan di lapangan mencakup: 
1. Penguatan monitoring dan evaluasi yang bisa dimulai dengan pembuatan roadmap yang jelas dan operasional untuk dilakukan secara jangka panjang dan mudah dipahami oleh para pelaku kegiatan;

2. Pelibatan masyarakat dalm gugus tugas khusus Sabilulungan 1000 kampung;

3. Pengembangan database yang transparan dan terintegrasi dengan data eksisting di kabupaten bandung; dan

4. Pemerataan biaya dan manfaat dengan penguatan forward and backward linkages melalui peran pemangku kepentingan dan fokus kegiatan di lingkup sub-kampung. Adapun konteks politik yang mengawal keberlangsungan dan keberlanjutan program ini membutuhkan perencanaan dan intervensi yang lebih sistematis, seperti menguatkan kualitas dan signifikansi perencanaan pembangunan jangka panjang dalam pembangunan Kabupaten Bandung.

\section{Saran}

Berdasarkan kesimpulan yang diperoleh dari penelitian ini maka disusun beberapa saran yang dapat dijadikan masukan dalam pelaksanaan kebijakan Sabilulungan 1000 Kampung di masa yang akan datang. Saran-saran tersebut antara lain:

1. Dari segi penyusunan kebijakan Sabilulungan 1000 Kampung:

a. Diperlukan inovasi dan pendalaman terhadap kebutuhan intervensi pemerintah dalam hal pembangunan sosial dan ekonomi masyarakat di samping pembangunan fisik kampung agar pembangunan ekonomi kampung berbasis potensi lokal mampu terwujud secara efektif dan efisien. Strategi yang dapat digunakan dalam pendalaman ini adalah menggunakan forum publik seperti Focus Group Discussion (FGD) untuk menggali sebanyak-banyaknya infomasi secara langsung melibatkan berbagai sektor dan stakeholder, dan penyusunan Participatory Rural Appraisal (PRA) untuk mampu memetakan kebutuhan kampung sesuai dengan masukan dari masyarakat lokal. Selanjutnya, dapat dikembangkan suatu gugus tugas dan pusat research and development untuk mengembangkan dan mengawal masukan-masukan dari pemangku kepentingan.

b. Diperlukan penyusunan rencana aksi yang lebih rinci dan berdasarkan hasil PRA yang telah dilakukan untuk tiap kampung yang akan dikembangkan. Adanya rencana aksi ini akan menjadi guide line atau acuan dalam pelaksanaan program 
dan kegiatan yang akan dilaksanakan di kampung agar tujuan, target, dan tahapan pelaksanaan kebijakan ini mampu tergambar dan terlaksana secara sesuai.

c. Dibutuhkan tim khusus multisektoral yang mengawal akselerasi pembangunan di tiap kampung dan memastikan kesesuaian pembangunan dengan perencanaan yang telah disusun sebelumnya melalui monitoring dan evaluasi berkala, baik dari segi anggaran, penanggung jawab, sampai dengan pencapaian target pembangunan.

d. Diperlukan suatu basis data terkait perencanaan, implementasi dan evaluasi kebijakan Sabilulungan 1000 Kampung yang dapat diakses oleh semua pemangku kepentingan secara transparan. Selanjutnya, data yang terhimpun dapat menjadi masukan untuk pelaksanaan research and development.

2. Dari segi sumber daya anggaran, dibutuhkan skema pendanaan alternatif selain anggaran yang bersumber dari APBD Kabupaten Bandung agar pelaksanaan program dan kegiatan di kampung lebih baik dari segi cakupan dan kualitasnya. Alternatif pendanaan yang dapat dijadikan opsi antara lain adalah yang melibatkan pihak swasta, seperti Corporate Social Responsibility (CSR) dan Kerjasama Pemerintah dan Badan Usaha (KPBU), mengingat pengembangan kampung yang tepat mampu memberikan keuntungan ekonomi tidak hanya bagi masyarakat tetapi juga untuk pihak swasta. Selain itu, dapat dikembangkan kerjasama pelatihan dengan start-up maupun dengan bentuk KPBU di bidang pemberdayaan UMKM untuk meningkatkan kompetensi pelaku usaha dalam Sabilulungan 1000 Kampung.

3. Dari segi waktu pelaksanaan kebijakan Sabilulungan 1000 Kampung, dibutuhkan perencanaan bertahap dalam penerapan kebijakan ini karena meski skala pembangunan sebatas kampung, tetapi dari sisi kedalaman pembangunan, untuk mengembangkan kampung sampai dengan mampu memproduksi, mengolah, dan mengelola ekonomi kampungnya sendiri secara berkelanjutan dibutuhkan pembangunan yang tepat sasaran dan pendampingan yang terus-menerus. Untuk mampu mewujudkan hal tersebut maka pembangunan di tiap kampung tidak cukup dialokasikan hanya dalam kurun satu tahun ataupun dalam waktu kepemimpinan 5 (lima) tahun. Dibutuhkan penguatan kualitas pada perencanaan pembangunan jangka panjang untuk menghindari diskontinuitas keberlangsungan program antarpemimpin 
daerah yang didukung oleh satu basis data perencanaan program Sabilulungan 1000 Kampung.

4. Dari segi evaluasi, guna mengingkatkan kualitas program Sabilulungan 1000 Kampung pada jangka yang lebih berkelanjutan maka penelitian ini juga merekomendasikan dikembangkannya indikator evaluasi keberhasilan program. Sebagaimana telah diidentifikasi dari pelaksanaan wawancara dan FGD dengan pemangku kepentingan di lapangan maka dalam mengevaluasi dan meningkatkan kinerja program Sabilulungan 1000 Kampung dengan perencanaan terpadu berbasis potensi dan kearifan lokal dapat dikerucutkan 3 (tiga) kriteria evaluasi utama, yakni mencakup kriteria keberlanjutan institusi, lingkup substansi, dan dampak. Selengkapnya masing-masing indikator utama dirinci sebagai berikut.

a. Kriteria keberlanjutan institusi, mencakup pengelolaan program dan peranserta pemangku kepentingan terkait. Di antaranya, kriteria ini dapat dirinci menjadi subkriteria sebagai berikut.

i. Posisi program pada rencana pembangunan daerah secara berjangka

ii. Jalur koordinasi para pemangku kepentingan dan tata kelola institusi terkait

b. Kriteria lingkup substansi, mencakup perancangan program yang komprehensif dan multisektor. Di antaranya, kriteria ini dapat dirinci menjadi sub kriteria sebagai berikut.

i. Aspek fisik, yakni menilai kegiatan-kegiatan yang berorientasi pada pembangunan fisik.

ii. Aspek pemberdayaan sumber daya manusia, yakni menilai kegiatankegiatan yang berorientasi pada pengembangan kapasitas SDM.

iii. Aspek inovasi, mencakup menilai tingkat penelaahan dan pengembangan penelitian berbasis data untuk menghasilkan proses pemecahan masalah yang lebih efektif dan efisien.

c. Kriteria dampak, mencakup pengendalian dampak yang tepat sasaran, responsif dan berkeadilan. Di antaranya, kriteria ini dapat dirinci menjadi sub kriteria sebagai berikut.

i. Dampak sosial, yakni menilai bagaimana program berdampak pada kapasitas individu dan masyarakat. 
ii. Dampak lingkungan, yakni menilai bagaimana program menghasilkan pencemaran pada lingkungan sekitar.

iii. Dampak ekonomi, yakni menilai bagaimana program meningkatkan kapasitas perekonomian masyarakat.

iv. Dampak spasial, yakni menilai bagaimana manfaat dan biaya program dapat menjangkau ataupun terkonsentrasi pada wilayah-wilayah tertentu.

\section{DAFTAR PUSTAKA}

Anderson, J. E. (1997). Public policymaking: An introduction. Boston: Houghton Mifflin.

Bromley, H. (1989). Identity Politics and Critical Pedagogy. Educational Theory, 39: 207-223. https://doi.org/10.1111/j.1741-5446.1989.00207.x

Dunn, W. (2003). Pengantar Analisis Kebijakan Publik (Terjemahann), Edisi Kedua. Jogjakarta: Gajahmada University Press.

Grindle, M.S. (2017). Good Governance, R.I.P.: A Critique and an Alternative. Governance, 30: 17-22. https://doi.org/10.1111/gove.12223

Mulyono, S. (2020). Peningkatan Kualitas Implementasi Kebijakan Melalui Pembentukan Kelembagaan Program Bandung 1000 Kampung.

Zulfikar, W \& Witartih, A. (2020). Evaluasi Program Bandung Seribu Kampung di Kabupaten Bandung. Jurnal Ilmiah Magister Administrasi, Vol 14, No 1. http://jurnal.unnur.ac.id/index.php/jimia/article/view/368/346 